\title{
The Reflection of Javanese Life Manner on the Dongkrek Art and Ritual Performance in Madiun Society
}

\author{
Sharfina Nur Amalina*; Djono Djono; Leo Agung Sutimin \\ Department of Teacher Training and Education, Sebelas Maret University, Indonesia \\ Email: sharfinaamalina@gmail.com
}

http://dx.doi.org/10.18415/ijmmu.v5i4.204

\begin{abstract}
This article focuses in the analysis of Javanese life manner within Dongkrek art and ritual performance in Mejayan, Madiun, Indonesia. The purpose of research is to reflect a life manner of Javanese society within a Dongkrek show. The qualitative-descriptive was used as research approach. Data were collected by interview, literature review, and other relevant resources. The results of research show a five points of Javanese manner of life in Dongkrek, represent in the phrase Ambrasta Dur Hangkara, Memayu Hayuning Bawana, Sura Dira Jayaning Lebur Dening Pangastuti, Sadulur Papat Kalima Pancer, and Manunggaling Kawula Gusti. Those phrases contain many moral values that generally can be accepted by society. The phrase represents a human relationship, the manner of life, ways of life, world-view, willingness, and the transcendental relationship between humans and God. It means the purpose of the Javanese manner of life is to reach the perfection of life. The perfection of life is resting on the faith towards to the God through the maturity of spirituality.
\end{abstract}

Keywords: Dongkrek Madiun; Manner of Life; Cultural Values; Javanese Tradition

\section{Introduction}

Indonesia is known as a pluralistic society, which has a richness of cultural diversity. The progress of a nation depends on its culture as a decisive element in the construction of civilization. The Javanese people have a knowledge that becomes their basic of thoughts and cultural history, in which the epistemology of Javanese thoughts is full of symbols as a medium to present their messages to other people. The Javanese culture contains a cultural value, ethics, and moral values, which is very important to be transmitted to the next generation. Those values are the product of Javanese culture that should be learned and understood by the society (Sartini., 2009).

The Javanese people put culture as an important aspect of their life. It is proved by Javanese proverb Budaya iku dadi kaca benggalaning bangsa or can be translated loosely in "culture becomes a great mirror which is reflecting the level of civilization". The proverb shows the Javanese perspective in looking the culture as a relative entity; every society owned their culture. Culture can be defined as all of the dialectical processes of humans from the thought, the soul, and the conscience, whether material or 
immaterial, as a notion that is adapted, implemented, and developed continuously and collectively by society (Kusumohamidjojo., 2009).

Refers to Geertz`s argumentation, arts or cultural performance can reflect the structure and system of society, and others aspect of society such as the manner of life, ways of life, and worldview. In the context of Javanese culture, those all aspect of society are symbolized behind the language, literacy, and art. The symbols are used as a medium to express their feeling, asceticism, spirituality, and religiosity (Herususanto., 2008).

The Javanese culture and art also covers the manners of life of Javanese people. The manner of life is the way in which persons give meaning to his life. The Javanese people are very concerned about simplicity, responsibility, highly respectful, caring, and humble feelings to the others. Inside of the manners, there is the philosophical aspect of Javanese people. Philosophy is the result of a human contemplation of the meaning of himself, the meaning of nature, and the purpose of his life by using the mind and is aided by the sense and belief that is within him, as a whole, which affects and helps others. Philosophy is used as guidance in giving the contents of life and strives to achieve his purpose in life (Nasroen., 1967).

The life manner or ways of thought is universal so it is not only used by Javanese people, but in wider context it is universally can be used by other society. This research reveals the life manner of Javanese people through a reflective interpretation of Dongkrek art performance that held by Mejayan community in Madiun, Indonesia.

\section{Dongkrek Tradition}

Dongkrek is an art tradition performance composed by Raden Ngabei Lo Prawirodipuro after Mejayan community faced a pagebluk. Pagebluk is a name for a period when deadly epidemic disease occurred abruptly in Madiun circa 1867. As a head village, Raden Ngabei Lo Prawirodipuro tried to overcome the problem, which then composed a ritual ceremony called Dongkrek. Dongkrek was a ritual, which reflected a hope for healing from illness and disaster. For further periods, this ritual transformed and spread as an art performances in East Java (Kutanegara, et al., 2012).

Dongkrek was born and flourished in the milieu of Javanese culture and society, so it reflects the manner and ways of thought of Javanese people. The ways of thought of Javanese people emphasize to reach harmonious situation and keselarasan (Rohman., 2013). The ways of thought of Javanese people relates to the Javanese philosophy. The ways of thought is a medium to find a perfection of life. In Javanese idiom, it called nudi kasampurnaan or try to find perfection in life. The human existence, physic and spirituality, is to reach their objectives that is perfection in life (Wibawa., 2013).

As a tradition, Dongkrek reflect a life manner or ways of thought of Javanese people. It contains the ethics and moral values that have a function to guide the human behave and attitude to reach a better life. At least Dongkrek arts performance has two meanings as a art performance as well as guidance. As a performance art, Dongkrek gives a show to people. Meanwhile, in the meaning as guidance, the Dongkrek want to present knowledge about old-tradition, which full of values and moral (Rohman., 2013).

Dongkrek art performance has five symbol of life, encompassing ambrasta dur angkara, Sura Dira Jayaning Lebur Dening Pangastuti, Sadulur Papat Kalima Pancer, and Manunggaling Kawula Gusti. Those five symbols will be describe in further explanation. 


\section{Ambrasta Dur Hangkara}

The meaning of words ambrasta dur hangkara relates to a consciousness that the human should pursue salvation, safety, happiness, and prosperity; and on the opposite diminish the nature of anger. This Javanese life manner is reflected in the history of Dongkrek. The background of the creation of Dongkrek ritual was the response of Raden Ngabei Lo Prawirodipuro, as a leader of the Mejayan region, to seek the safety and prosperity of his people against an epidemic disease disaster.

Raden Ngabei Lo Prawirodipuro attempted to diminish disease outbreak that spread in the Mejayan community. He then did semedi or a meditation pulled over, brooded, and asked for directions to the Almighty to get answers from his efforts to get rid of the plague. In the process of semedi, Raden Ngabei Lo Prawirodipuro got a dream. Four gendruwo or evil creatures, who claimed that they are cause of pageblug in the region Mejayan, attacked him. Raden Ngabei Lo Prawirodipuro tried to attack gendruwo but was unshakeable. Suddenly, a beam of white light turned into an old man who gave Raden Ngabei Lo Prawirodipura a weapon namely cemethi sada lanang to drive him away.

Eventually, gendruwo were subdued and begged forgiveness to Raden Ngabei Lo Prawirodipuro. Raden Ngabei Lo Prawirodipuro, who had mercy, pardoned genderuwo in some points that they should help him get rid of the disaster. From his dream, then Raden Ngabei Lor Prawirodipuro believes that in order to stop the outbreak of the disease was by a ritual in accordance with the dream that he found (Walgito., 2017).

The effort of Raden Ngabei Lo Prawirodipuro to asking for guidance to save Madiun society from pagebluk outbreak is a reflection of Javanese life manner of ambrasta dur hangkara. Ambrasta dur hangkara is defined as the attitude of life and the willingness to cultivate the safety of others, happiness, also prosperity of Madiun society. He succeed eradicated the nature of angkara that perpetrated by genderuwo. From the instruction obtained Raden Ngabei Lor Prawirodipure, was then derived in form of ritual ceremonies to expel the disease by transform it to a dance. The dance was shown by a parade around the village. Pagebluk repellent dance is then become a sacred dance, currently also as a folk entertainment namely Dongkrek Madiun.

\section{Memayu Hayuning Bawana}

The Javanese leader has shibboleths as a life guidance that should be followed. The leader should have some characters, which represent in words hamangku, hamengku, and hamengkoni. Hamangku is defined as attitudes and willingness to protect the others. Hamengkoni refers to a sense of always being protective in all situations. In Javanese perspective, the leader should always dare to be responsible, acknowledge his people as part of his life, and always protect his follower in all conditions and situations (Sartini., 2009).

Memayu hayuning bawana means a philosophy of leadership that always strives to improve the welfare of the people and encourage the creation of attitudes and behavior of individual life. It emphasizes harmony among human as well as between human and nature, and the most important this is the relation to the God.

The philosophy of memayu hayuning bawana also implies an obligation to protect, nurture and salvation of the world to prioritize the interests of society rather than private or group interests. Memayu hayuning bawana can be translated in two meaning. Bawana is understood as tangible and intangible, and as bawana alit (little world) and bawana ageng (great world). In such of an understanding, this concept becomes a reference for family, society and state. This concept implies an obligation to protect, nurture 
and nurture the salvation of the world and to prioritize the interests of the community rather than the personal or group interests.

The manner that reflects the concept of memayu hayuning bawana is an acts to protect social life. In the Dongkrek art performance, memayu hayuning bawana reflect in the business of Raden Ngabei Lo Prawirodipuro to protect Mejayan community. It stipulates that to provide prosperity and a sense of security, the people of Mejayan should always perform the Dongkrek ritual ceremony every year. The purpose of routinization is to seek the welfare of society and protect it from other bad things as anticipation form the petition to the Almighty.

Dongkrek ritual ceremony performed every night $1^{\text {st }}$ night of sura. Dongkrek ritual ceremonies are still shown every once a year by doing a parade around the village. The procession is playing the Dongkrek dance with all its properties, masks, and musical instruments that accompany it.

\section{Sura Dira Jayaningra Lebur Dening Pangastuti}

Javanese people is known as a society, which has smooth, gentle, and humble characters, who does not like to look for trouble and so on. The Javanese people have a vigorous attitude of life and a strong determination in solving problems and determination to achieve something. It is actualized in the expression Sura Dira Jayaningrat Lebur Dening Pangastuti.

Sura Dira Jayaning Lebur Dening Pangastuti has meaning that all bad natures will only be defeated with good or wise natures. The Javanese life manner suggests that anyone should dare to eradicate evil and defend the truth. The belief that evil can be defeated by goodness reflects the local wisdom that needs to be lived in order to keep the community has a strong determination and passion in achieving the ideals in life and life.

The Javanese people believe that all good natures will always meet with bad or evil attitude. This manner is reflected in the Dongkrek show that the bad attitude as depicted by the genderuwo is ultimately lost to the good manner of Raden Ngabei Lo Prawirodipuro. Genderuwo as a bad nature finally subdued. Raden Ngabei Lo Prawirodipuro and Mejayan community believe that all evil can be defeated with a good nature, so through they perceived that the Dongkrek ritual ceremony paraded around the village of Mejayan could defeat or eliminate disease outbreaks that disrupt the citizens.

\section{Sedulur Papat Kalima Pancer}

The meaning of sedulur papat kalima pancer or can be translated as "the four brothers and the guide as the fifth brother, are the four passions that can be guided and controlled by man himself. In Javanese society, good and bad manner are regarded as inseparable in from of human existence, incarnate in various desires, and associated with four passions (Ciptoprawiro., 1986). The four passions are mutmainah, anger, aluwamah, and supiah. Good wishes (mutmainah) will always facing bad desires (anger, aluwamah, and supiah) to incarnate human behavior.

In the context of Dongkrek art, sedulur papat kalima pancer has a message to control lust. The message is conveyed through the symbol of gendruwo, which reflect on the Dongkrek show in form of colorful mask. The colorful mask is the symbol of human traits: red, white, black, and yellow. Red is seen as a symbol of anger that describes the nature and character of evil. Red also shows a spooky, angry, emotional and rough temperament. White is the symbol of an inner calm (mutmainah), which also shows as a good character. White also describe manner that has the etiquette and humanism. White is transmitted 
in from of the life resources such as water, wind, clean, clear and purity. Black mask illustrates bad manner. Black gendruwo shows the character of lazy, greedy, jealous, and fierce arrogant. The bad manner of black gendruwo reflects the nature of human aluamah. Yellow reflect the nature of desire or supiyah. (Rohman., 2013).

During his life, human are required to be able to control their passions or traits. Dongkrek artistry depicts the Javanese mindset that humans are not protracted in worldly passions. By being able to control the temporal lust, the Javanese people is expected to achieve a last manner of life, that is jumbuhing kawula gusti. Jumbuhing kawula gusti is the attitude of life that all people should be able to reach for inner peace.

\section{Manunggaling Kawula Gusti}

Hardjowirogo explains the dimension of Javanese belief such as vertical line, which is measured from the understanding and concrete action as the Lord's servant. The Javanese people always try to put themselves in right position. It symbolized in word ngawula (tat to God) and mayawan sawantah (just slave), tepa slira (understand others), become the original manner and character of Javanese society (Mulyana., 2006).

The speculation of Javanese beliefs, perhaps, is the acceptance of the teachings of pantheism (union between the subjects and lord, the servant of God) (Mulyana., 2006). Zoetmulder spelled out the phrase, man in God, and God in man. The phenomenon is understandable, with an early assumption, that the Javanese generally have a tendency to approach, the willingness to unite with the creator, and in various demands that are sometimes very individual. In many ways, the Javanese can hardly be released from the behavior of symbolism. Beliefs, languages, and deeds are filled with a thick symbol of spiritualism (Zoetmulder., 1991).

The manner of Ngudi Kasampurnan is always looking for perfection in life. Manunggaling kawula gusti has the meaning of unity of small world and great world to unity humans with God Almighty. Spirit that express in this words is everyone should always try as hard as possible to seek God. It is continuing to search for human life will continue to run. All these things are based on the spirit of this desire, to bring human relationship closer to God as close as possible. This idealization is actualized through the expression of manunggaling kawula gusti, the unity of nature and the great nature (Sartini., 2009).

The phrase of manunggaling kawula gusti appears with the background; the inability of man to explain all the natural phenomena in his seeing and feeling. The human desire to seek the rest of life can guide to the initiative, creation, and his work; the closeness between the Javanese with the Creator (Pranowo., 2003). With the attainment of such attitudes, good and bad contradictions such as in the attitude of sadulur papat kalima pancer will be overcome by increasing awareness. Increased awareness is called as the kadewasan jiwa or the maturity of the human soul. Decency is inseparable from the behavior on the way to perfection. Man's maturity will form a character, which then determines his behavior.

The manner of manunggaling kawula gusti in Dongkrek art performance is reflected in the efforts of Raden Ngabei Lo Prawirodipuro and Madiun society to get closer to God Almighty. Attempts to get closer are done by carrying out the ritual Dongkrek once a year. who hopes to ask for protection to God Almighty to be given the welfare of life free of calamity and ugliness. The ritual ceremony and the Dongkrek show is a form of Madiun's public prayer request. 


\section{Conclusion}

The manner of Javanese in Dongkrek that is symbolized in Javanese expressions such as Ambrasta Dur Hangkara, Memayu Hayuning Bawana, Sura Dira Jayaning Lebur Dening Pangastuti, Sadadi Papat Kalima Pancer, and Manunggaling Kawula Gusti, contains many moral values and teachings that can be accepted by other society. The values and teachings can be summarized in a manner in humans relationship, a worldview of Javanese people concerning to determination, a human relationship with God. The manner has a function to achieve the life purposes: perfection of life. This perfection of life is including harmony and wisdom in thinking and behaving. The main objectives of Javanese people, which represent in Dongkrek is to be closer to the One Almighty.

\section{References}

Bratawijaya, Thoms W. (1997). Mengungkap dan Mengenal Budaya Jawa. Jakarta: Pradnya Paramita.

Ciptoprawiro, A. (1986). Filsafat Jawa. Jakarta: Balai Pustaka.

Geertz, Cliffort. (1964). The Religion of Java. London : The Free Press of Glancoe.

Hana, Judith Lynne. (1988). Dance and Ritual. Journal of Physical Edication, Recreation \& Dance, 59(9).

Hanif, M. (2016). Kesenian Dongkrek (Studi Nilai Budaya dan Potensinya sebagai Sumber Pendidkan Karakter). Gulawentah, 1(2).

Hartini. (t.thn.). Kajian Nilai, Fungsi dan Makna yang Terkandung dalam Seni Dongkrek. Jurnal Program Studi PGSD FIP FKIP Madiun.

Herususanto, B. (2008). Simbolisme Jawa. Yogyakarta: Ombak.

Jaecken, M. (2011). Seni Dongkrek Kecamatan Mejayan Kabupaten Madiun tahun 1965-1981. Surakarta: Hasil Penelitian Metodologi Sejarah Jurusan Ilmu Sejarah FSSR UNS.

Jong, S de,. (1976). Salah Satu Sikap hidup Orang Jawa. Yogyakarta: Kanisius.

Kusumohamidjojo. (2009). Filsafat Kebudayaan. Yogyakarta: Jalasutra.

Kutanegara, P. M., Susilantini, E., Nurwanti, Y. H., Suyami, Rohman, Suryadmaja, G., et al. (2012). Revitalisasi Kesenian Dongkrek dalam Rangka Penguatan Budaya Lokal : Studi Kesenian Dongkrek Desa Mejayan Kecamatan Mejayan Madiun. Yogyakarta: Balai Pelsetarian Nilai Budaya (BPNB).

Mulder, Niels. (1983). Pribadi dan Masyarakat di Jawa: Penjelajahan mengenai Hubungannya. Jakarta: Sinar Harapan.

Mulyana. (2006). Spiritualisme Jawa : Meraba Demensi dan Pergulatan Religius Orang Jawa. Kejawen, 4. $1(2)$.

Nasroen, M. (1967). Falsafah dan Cara Berfalsafah. Jakarta: Bulan Bintang.

O'P Anderson, Benedict R. (1999). Indonesia Nationalism Today and in The Future. Art \& Humanities Database: Indonesia. 
Pranowo. (2003). Ungkapan Bahasa Jawa sebagai Pendukung Pembentukan Kebudayaan Nasional. Linguistik Indonesia, 2: 269-286.

Rohman. (2013). Kesenian Dongkrek, Pandangan Dunia, dan Nilai Kebijaksanaan. Jantra, 85.

Sartini, N. W. (2009). Menggali Nilai Kearifan Lokal Budaya Jawa Lewat Ungkapan (Bebasan, Saloka, dan Paribasa). Jurnal Ilmiah Bahasa dan Sastra, 29. V(1) .

SJ, F. M. (2017). "Rumah Makna". Dalam J. Daoed, Nilai-Nilai Keindonesiaan (hal. 55). Jakarta: Kompas Media Nusantara.

Walgito. (2017). Interview of "Dongkrek History" on his community, Mejayan.

Wibawa, S. (2013). Filsafat Jawa. Yogyakarta: Universitas Negeri Yogyakarta.

Zoetmulder, P. (1991). Manunggaling Kawula Gusti. Pantheisme dan Monisme dalam Paham Suluk Jawa. Jakarta: Gramedia.

\section{Copyrights}

Copyright for this article is retained by the author(s), with first publication rights granted to the journal.

This is an open-access article distributed under the terms and conditions of the Creative Commons Attribution license (http://creativecommons.org/licenses/by/4.0/). 